\title{
Features of physician services databases in Canada
}

\section{M. Lix, PhD (1); R. Walker, MSc (2); H. Quan, PhD (2); R. Nesdole, MEd (1); J. Yang, BSc (3); G. Chen, PhD (2); for the CHEP-ORTF Hypertension Outcomes and Surveillance Team}

This article has been peer reviewed.

\begin{abstract}
Introduction: Physician services databases (PSDs) are a valuable resource for research and surveillance in Canada. However, because the provinces and territories collect and maintain separate databases, data elements are not standardized. This study compared major features of PSDs.
\end{abstract}

Methods: The primary source was a survey of key informants that collected information about years of data, patient/provider characteristics, database inclusions/exclusions, coding of diagnoses, procedures and service locations. Data from the Canadian Institute for Health Information's (CIHI) National Physician Database were used to examine physician remuneration methods, which may affect PSD completeness. Survey data were obtained for nine provinces and two territories.

Results: Most databases contained post-1990 records. Diagnoses were frequently recorded using ICD-9 codes. Other coding systems differed across jurisdictions and time, although all PSDs identified in-hospital services and distinguished family medicine from other specialties. Capture of non-fee-for-service records varied and CIHI data revealed an increasing proportion of non-fee-for-service physicians over time.

Conclusion: Further research is needed to investigate the potential effects of PSD differences on comparability of findings from pan-Canadian studies.

Keywords: administrative health databases, physician services, medical insurance programs, International Classification of Diseases

\section{Introduction}

Administrative health data, which are collected to monitor and manage health systems, are a rich resource for research and surveillance in Canada. The data are obtained from multiple sectors including health insurance registration systems, inpatient facilities, emergency departments, medical services plans, vital statistics files and prescription drug systems. Increasingly, administrative data are being used to conduct pan-Canadian studies on population health and the use of health services. For example, the Public Health Agency of Canada's Canadian Chronic Disease Surveillance System uses diagnoses recorded in hospital and physician records to estimate prevalence and incidence for such conditions as diabetes and hypertension for all Canadian provinces and territories. ${ }^{1-3}$ Multi-province chronic disease studies using administrative data have also been undertaken for rheumatic diseases, inflammatory bowel disease and mental disorders, ${ }^{4-6}$ and are underway for other conditions, including hypertension. ${ }^{7} \quad$ Administrative health data are appealing for research and surveillance because they provide an economical alternative to primary data collection, encompass entire populations and span multiple years.

Despite the many advantages of administrative health data, their use is not without challenges. Canada has a system of universal health care, but the delivery of services is a provincial and territorial responsibility. The collection and management of most administrative data are undertaken using information systems developed for each province and territory, which may contribute to a lack of standardization and harmonization in how the data are collected and recorded. Exceptions are the national hospital databases developed by the Canadian Institute for Health Information (CIHI), including the Discharge Abstract Database and the Hospital Morbidity Database, which use a common abstraction form and quality evaluation methodology.

Data quality is a relevant research topic in today's environment, where large databases are frequently used for decision making and policy development. ${ }^{8}$ Researchers, epidemiologists and decision makers interested in undertaking panCanadian studies could benefit from results of comparisons of administrative health data from different jurisdictions. Information about features of these data can facilitate developing quality evaluation methodologies and research protocols to investigate the potential impact of differences on study findings. Physician services databases (PSDs), which contain billing records or claims for physician

\section{Author references:}

1. School of Public Health, University of Saskatchewan, Saskatoon, Saskatchewan, Canada

2. Department of Community Health Sciences, University of Calgary, Calgary, Alberta, Canada

3. Western College of Veterinary Medicine, University of Saskatchewan, Saskatoon, Saskatchewan, Canada

Correspondence: Lisa Lix, School of Public Health, University of Saskatchewan, 107 Wiggins Road, Saskatoon, SK S7N 5E5; Tel.: (306) 966-1617; Fax: (306) 966-7920; Email: lisa.lix@usask.ca 
contacts with patients, are particularly important for chronic disease research and surveillance. They are a source of diagnosis and procedure information for outpatient visits, and contain information about contacts with both primary care and specialist physicians. Given this background, the purpose of this study was to compare major features of PSDs in Canada's provinces and territories. A paper on this topic is critical to establishing a baseline level of scientific knowledge. Further, this article will likely remain relevant for some time because many database features, including first year of data accessible to researchers, International Classification of Diseases (ICD) version, number of diagnosis fields, specificity of diagnosis fields and availability of information about outof-province services, are unlikely to change quickly; in fact, they have been static in several provinces and territories over recent years.

\section{Methods}

The primary source of data for this study was a survey, emailed to key informants from all provinces and territories, to collect information about selected features of PSDs. Published CIHI reports were a secondary source of data, and were used to collect information about the ways physicians are remunerated, a factor that can affect completeness of PSDs. ${ }^{8}$

Key informants were primarily identified from the membership of the Hypertension Outcomes and Surveillance Team (HOST), ${ }^{9}$ a subgroup of the Canadian Hypertension Education Program Outcomes Research Task Force (CHEP-ORTF). HOST includes approximately 20 researchers, analysts and government representatives from British Columbia, Alberta, Saskatchewan, Manitoba, Ontario and Quebec as well as from the Public Health Agency of Canada and Statistics Canada. Members of HOST have expertise in health services or population health research or surveillance using administrative data. In those provinces or territories that have no HOST member, we contacted HOST collaborators, individuals employed by ministries of health who facilitate access to administrative data and documentation for research purposes. Up to two individuals from each province and territory were contacted to participate in the study.

Study investigators developed the survey based on earlier research on features of administrative health data. ${ }^{10}$ The survey included questions about the years of data available for researcher access and the availability and contents of fields for patient and provider information, patient diagnosis and procedure codes, out-of-province services and services of providers paid by non-fee-for-service methods. Physician fee schedules were also consulted as a source of information about remuneration methods. ${ }^{11}$ Open-ended response categories were used for all survey questions.

Key informants were initially contacted in June 2010. Follow-up questions and online documentation about PSDs was used to clarify responses and to develop additional questions. A second round of questionnaires was sent to the key informants in November 2010 to obtain more detailed information about PSD features.

Secondary data published by CIHI were used to compile additional information about non-fee-for-service (i.e. alternate clinical) providers and payments. ${ }^{12-14}$ The data were from reports based on the National Physician Database, which contains aggregate physician payment data from provincial and territories medical services plans. Information about the National Physician Databases and the data collection methodology was previously published. ${ }^{12,15}$

Ethics approval for the HOST project, which includes the extraction and analysis of administrative health data from the provinces and territories and the collection and reporting of documentation associated with the administrative health data, was obtained from the University of Calgary Research Ethics Board (Ethics Review \#E188889). The analysis of publicly available data from CIHI did not require ethics approval.

\section{Results}

Key informants from all provinces and territories except New Brunswick responded to the survey, though only partial information was available from the Northwest Territories. As a result, New Brunswick and Northwest Territories were excluded from the analysis of the survey data.

\section{PSD availability}

The survey results indicate that PSDs in Canada contain records from as early as 1970 (see Table 1); the range for the first accessible year of data was 24 years. The Manitoba and Saskatchewan databases contain the oldest records, from the early 1970s. Databases for four provinces hold records from the 1980s. However, Quebec and Alberta reported that some of the earliest records were not easily accessed because they were archived and/or in a format different to more recent records. The other provinces and territories reported that their databases contained records from the 1990s.

\section{Patient and provider information}

The survey results also revealed that all PSDs contain unique patient and provider identifiers (Table 1). With appropriate permissions, these identifiers can be used to link the databases to other sources. For example, linkage to a population registry file can be used to obtain dates of coverage by provincial health insurance plans, residence information (e.g. postal code or geographic area), birthdates or age, and sex.

All databases also record provider specialty. The number of specialist categories reported by respondents ranged from about 25 to more than 80 . However, broad groupings of family medicine, medical specialties, and surgical specialties were identified in the categories provided by all provinces and territories. At the same time, there was a heterogeneous mix of provider specialties in the "other" category. Depending on the jurisdiction, this category could include nurse practitioners, midwives, pharmacists or other allied health professionals. Most respondents indicated that provider specialty was assigned by each jurisdiction's medical services plan at the time the service record was submitted for payment. 
TABLE 1

Major features of physician services databases by province or territory: data availability, patient, provider

\begin{tabular}{|c|c|c|c|c|c|}
\hline $\begin{array}{l}\text { Province/ } \\
\text { Territory }\end{array}$ & $\begin{array}{l}\text { First year of data } \\
\text { accessible to researchers }\end{array}$ & $\begin{array}{l}\text { Patient } \\
\text { identifier }\end{array}$ & $\begin{array}{c}\text { Patient } \\
\text { demographics }^{\mathrm{a}}\end{array}$ & $\begin{array}{l}\text { Provider } \\
\text { identifier }\end{array}$ & Provider categories and specialties \\
\hline $\begin{array}{l}\text { British } \\
\text { Columbia }\end{array}$ & 1990 & $\checkmark$ & $\checkmark$ & $\checkmark$ & $\begin{array}{l}50+\text { categories from family medicine, medical, surgical, other. } \\
\text { Multiple specialty fields defined. }\end{array}$ \\
\hline Alberta & $\begin{array}{l}1982 \text {; data prior to } 1994 \\
\text { are in a different format }\end{array}$ & $\checkmark$ & $\checkmark$ & $\checkmark$ & $\begin{array}{l}60+\text { categories from family medicine, medical, surgical, other. } \\
\text { Specialty defined by the payment plan. }\end{array}$ \\
\hline Saskatchewan & 1971 & $\checkmark$ & $\checkmark$ & $\checkmark$ & $\begin{array}{l}70+\text { categories from family medicine, medical, surgical, other. } \\
\text { Specialty defined by physician certification. }\end{array}$ \\
\hline Manitoba & 1970 & $\checkmark$ & $\checkmark$ & $\checkmark$ & $\begin{array}{l}80+\text { categories from family medicine, medical, surgical, other. } \\
\text { Multiple specialty fields defined. }\end{array}$ \\
\hline Ontario & 1991 & $\checkmark$ & $\checkmark$ & $\checkmark$ & $\begin{array}{l}35+\text { categories from family medicine, medical, surgical, other. } \\
\text { Multiple specialty fields defined. }\end{array}$ \\
\hline Quebec & $\begin{array}{l}\text { 1983; data prior to } 1996 \\
\text { are in a different format }\end{array}$ & $\checkmark$ & $\checkmark$ & $\checkmark$ & $\begin{array}{l}\text { One field distinguishes family physicians from specialists. } \\
\text { A second field identifies the type of specialty. } 60+\text { categories } \\
\text { are identified from family medicine, medical, surgical, other. } \\
\text { Specialty defined by physician training. }\end{array}$ \\
\hline $\begin{array}{l}\text { Prince Edward } \\
\text { Island }\end{array}$ & $\begin{array}{l}\text { 1983; Data prior to } 1996 \\
\text { are archived }\end{array}$ & $\checkmark$ & $\checkmark$ & $\checkmark$ & $\begin{array}{l}45+\text { specialty code descriptions within family medicine, medical, } \\
\text { surgical, other. Specialty defined by the services provided. }\end{array}$ \\
\hline Nova Scotia & 1989 & $\checkmark$ & $\checkmark$ & $\checkmark$ & $\begin{array}{l}50+\text { categories from family medicine, medical, surgical, other. } \\
\text { Billing specialty and main specialty defined. }\end{array}$ \\
\hline $\begin{array}{l}\text { Newfoundland } \\
\text { and Labrador }\end{array}$ & 1995 & $\checkmark$ & $\checkmark$ & $\checkmark$ & $\begin{array}{l}80+\text { categories from family medicine, medical, surgical, other. } \\
\text { Specialty defined by physician training. }\end{array}$ \\
\hline Yukon & 1995 & $\checkmark$ & $\checkmark$ & $\checkmark$ & $\begin{array}{l}25+\text { categories from family medicine, medical, surgical. Specialty } \\
\text { defined by physician certification. }\end{array}$ \\
\hline Nunavut & 1999 & $\checkmark$ & $\checkmark$ & $\checkmark$ & $\begin{array}{l}\text { Approximately } 70 \% \text { of records are coded as generalist or specialist } \\
\text { physician. The remaining records are missing information about } \\
\text { physician specialty. }\end{array}$ \\
\hline
\end{tabular}

Note: Incomplete or no survey data was available for New Brunswick and Northwest Territories. As a result, these were excluded from the analysis.

${ }^{a}$ Includes date of birth or age, sex, location of residence (e.g. postal code, health region or county)

\section{Diagnosis and procedure information}

Table 2 shows information about diagnosis and procedure codes, as identified by the survey respondents. ICD codes were used to record the majority of diagnoses in all jurisdictions. In Saskatchewan and Manitoba, ICD-8* diagnosis codes were primarily used in the 1970s. Three jurisdictions, Manitoba, Alberta and Nunavut, use ICD-9-CM codes $^{\dagger}$. In Yukon, diagnoses are recorded using ICD-9 $9^{\ddagger}$ codes as well as a free-form text format. In Ontario, data contain both ICD-8 and ICD-9 codes, although neither system is used in its entirety. In Saskatchewan, not all ICD-9 codes are used to assign diagnosis.

Respondents from all but three provinces reported that a single diagnosis is recorded for each claim in their PSDs.
For British Columbia, up to three diagnosis fields may be present on some of the claim records. Nova Scotia's database contains three diagnosis codes for selected years. Alberta's database also contains three diagnosis fields, although respondents noted that the second and third fields were not consistently coded in all records. The Yukon and Nunavut databases contain multiple diagnosis fields.

Diagnosis codes were recorded with different degrees of specificity, with three-digit codes being most common. While procedural information was most commonly identified from service fee codes, other procedure coding systems were adopted, including the Canadian Classification of Procedures in both Nova Scotia and Alberta.

\section{Location of services}

Survey respondents reported that not all PSDs contain a field or fields to identify location of service (see Table 3); service fee codes and billing location are sometimes required to ascertain service location. However, in all provinces and territories, it is possible to distinguish in-hospital services from those provided in other locations.

\section{PSD inclusions and exclusions}

Table 3 also contains survey information about records from out-of-province providers. Respondents from four provinces (Newfoundland and Labrador, Nova Scotia, Manitoba, and British Columbia) reported that these records were contained in a separate database. For

\footnotetext{
* International Classification of Diseases, Eighth Revision.

† International Classification of Diseases, Ninth Revision, Clinical Modification.

* International Classification of Diseases, Ninth Revision.
} 
TABLE 2

Major features of physician services databases in Canada: diagnoses and procedures

\begin{tabular}{|c|c|c|c|c|c|}
\hline $\begin{array}{l}\text { Province/ } \\
\text { Territory }\end{array}$ & ICD version & $\begin{array}{l}\text { Number of } \\
\text { diagnosis fields }\end{array}$ & $\begin{array}{l}\text { Specificity of diagnosis codes } \\
\text { (number of digits) }\end{array}$ & $\begin{array}{l}\text { Source of procedure } \\
\text { information }\end{array}$ & $\begin{array}{l}\text { Other information about diagnosis/ } \\
\text { procedure fields }\end{array}$ \\
\hline $\begin{array}{l}\text { British } \\
\text { Columbia }\end{array}$ & ICD-9 & $\begin{array}{c}\text { Most claims } \\
\text { contain } 1 \text { code, but } \\
\text { some primary care } \\
\text { physicians record } \\
\text { up to } 3\end{array}$ & $\begin{array}{l}\text { Up to } 5 \text {, but } 3 \text { digits } \\
\text { are the most common }\end{array}$ & Fee codes & $\begin{array}{l}\text { ICD-9-CM codes are also found in some } \\
\text { claims. Some diagnosis codes are specific } \\
\text { to the provincial medical services plan. }\end{array}$ \\
\hline Alberta & ICD-9-CM & 3 (1 before 1994) & $\begin{array}{l}\text { Up to } 5 \text {, but the } 5^{\text {th }} \text { digit is not } \\
\text { well recorded; 3-digit codes were } \\
\text { used before } 1994\end{array}$ & $\begin{array}{l}\text { Canadian } \\
\text { Classification of } \\
\text { Procedures }\end{array}$ & \\
\hline Saskatchewan & $\begin{array}{l}\text { ICD-8 until 1978, } \\
\text { then ICD-9 }\end{array}$ & 1 & 3 & Fee codes & $\begin{array}{l}\text { Some diagnostic codes assigned by the } \\
\text { province are also used and some ICD-9 } \\
\text { codes (including all E-codes and selected } \\
\text { other codes) are not used. }\end{array}$ \\
\hline Manitoba & $\begin{array}{l}\text { ICD-8 until 1979, } \\
\text { then ICD-9-CM }\end{array}$ & 1 & 3 & $\begin{array}{l}\text { ICD-9-CM and fee } \\
\text { codes }\end{array}$ & \\
\hline Ontario & $\begin{array}{l}\text { Hybrid of ICD-8 } \\
\text { and ICD-9 }\end{array}$ & 1 & $\begin{array}{l}\text { 3; a 1-digit suffix is } \\
\text { added for physiotherapy and } \\
\text { chiropractic codes }\end{array}$ & Fee codes & $\begin{array}{l}\text { Not all ICD-8 and }-9 \text { diagnosis codes } \\
\text { are found in the database. }\end{array}$ \\
\hline Quebec & ICD-9 & 1 & 4 & $\begin{array}{l}\text { Province-specific } \\
\text { codes }\end{array}$ & \\
\hline $\begin{array}{l}\text { Prince Edward } \\
\text { Island }\end{array}$ & ICD-9 & 1 & $\begin{array}{l}\text { 3, except for E-codes and } \\
\text { V-codes, which are } 5 \text { digits }\end{array}$ & ICD-9 and fee codes & \\
\hline Nova Scotia & ICD-9 & 3 (1 before 1997) & $\begin{array}{l}\text { Up to } 5 \text {; 3-digit codes are } \\
\text { the most common and were } \\
\text { used before } 1997\end{array}$ & $\begin{array}{l}\text { Modified version } \\
\text { of CCP. A single code } \\
\text { is recorded }\end{array}$ & $\begin{array}{l}\text { Some E-codes are captured in an } \\
\text { "injury diagnosis" field, but the capture } \\
\text { rate or completeness is not known. }\end{array}$ \\
\hline $\begin{array}{l}\text { Newfoundland } \\
\text { and Labrador }\end{array}$ & ICD-9 & 1 & 3 & Fee codes & \\
\hline Yukon & ICD-9 + text & $\begin{array}{l}2 \text { before } 2006 \text {, } \\
\text { unlimited since then }\end{array}$ & $\begin{array}{l}\text { Up to } 5 \text { but most records } \\
\text { use only } 4\end{array}$ & Fee codes & \\
\hline Nunavut & ICD-9-CM & 11 & 5 & None & $\begin{array}{l}\text { The databases support the collection } \\
\text { of procedure codes, but this information } \\
\text { is not currently captured. }\end{array}$ \\
\hline
\end{tabular}

Abbreviations: E-codes, external cause of injury codes; ICD-8, International Classification of Diseases, Eighth Revision; ICD-9, International Classification of Diseases, Ninth Revision;

ICD-9-CM, International Classification of Diseases, Ninth Revision, Clinical Modification; V-codes, supplemental codes.

Note: Incomplete or no survey data was available for New Brunswick and Northwest Territories. As a result, these were excluded from the analysis.

the remaining provinces and territories, respondents noted that a specific code or field within the PSD could be used to identify out-of-province records.

The collection of records from fee-for-service and non-fee-for-service physicians was the final topic of inquiry. With the exception of Newfoundland and Labrador and of Quebec, respondents indicated that PSDs in all jurisdictions contain records of services provided by non-fee-for-service physicians. However, respondents also indicated that the completeness of capture of records from non-fee-for-service physicians was not consistently known. This might be due to changes in medical service plans over time and/or a lack of documentation about alternate payment plans. Respondents from six jurisdictions reported that PSDs contain a field to distinguish records submitted by fee-for-service physicians from those submitted by non-fee-for-service physicians. In three provinces, information from a provider registry is needed to distinguish these two types of records.

\section{$\mathrm{CIHI}$ data on physician remuneration methods}

The secondary data from CIHI were used to investigate physician remuneration methods across jurisdictions, which may affect the completeness of PSDs. Data from the territories were not consistently available and are therefore not reported. In Figure 1, the percentage of full-time equivalent physicians remunerated by non-fee-forservice (i.e. alternate clinical) payment methods are reported for fiscal years $1999 / 2000$ and 2005/2006; the last year is the most recent available from CIHI. This percentage increased in all provinces, except for British Columbia and for
Newfoundland and Labrador. The largest absolute increase occurred in New Brunswick (17.3\%) and Prince Edward Island (15.0\%). When the data from the four Atlantic provinces were combined, the percentage of full-time equivalent physicians remunerated by alternate clinical payments rose from $20.3 \%$ to $25.6 \%$. Saskatchewan also saw a large absolute increase $(6.5 \%)$. Figure 2 provides data about alternative clinical payments to physicians in fiscal years $1999 / 2000$ and 2008/2009. Overall, payments in the four Atlantic provinces increased from $23.8 \%$ to $39.8 \%$. Large increases between the two study years were also observed in Ontario and Saskatchewan.

\section{Discussion}

We identified only one other published paper that systematically documented the features of PSDs in Canada; it focused on 
TABLE 3

Major features of physician services databases in Canada: service location and completeness

\begin{tabular}{|c|c|c|c|c|}
\hline $\begin{array}{l}\text { Province/ } \\
\text { Territory }\end{array}$ & Location of service categories & $\begin{array}{l}\text { Out-of-province } \\
\text { services }\end{array}$ & Shadow-billed records & Shadow-billing indicator \\
\hline $\begin{array}{l}\text { British } \\
\text { Columbia }\end{array}$ & $\begin{array}{l}\text { Province and out-of-country locations are identified. } \\
\text { Service locations including hospitals and clinics are available } \\
\text { from } 1990 .\end{array}$ & $\begin{array}{l}\text { Recorded in a } \\
\text { separate database }\end{array}$ & $\begin{array}{l}\text { Yes, but completeness } \\
\text { is unknown }\end{array}$ & $\begin{array}{l}\text { Yes. As of } 1999 \\
\text { shadow-billed claims can } \\
\text { be identified using a flag. }\end{array}$ \\
\hline Alberta & Service locations are identified from address information. & $\begin{array}{l}\text { Identified in one } \\
\text { field in the database }\end{array}$ & $\begin{array}{l}\text { Yes, but completeness } \\
\text { is unknown }\end{array}$ & Yes \\
\hline Saskatchewan & $\begin{array}{l}\text { Office, hospital inpatient, hospital outpatient, home, other, } \\
\text { location not indicated, emergency room physician. Fee } \\
\text { codes are also used to identify services provided in hospital. } \\
\text { Location of services became a required field in the } 1980 \text { s, } \\
\text { but the exact date is not known. This field is not validated. }\end{array}$ & $\begin{array}{l}\text { Identified by a field } \\
\text { in the database }\end{array}$ & $\begin{array}{l}\text { Yes, but completeness } \\
\text { is unknown }\end{array}$ & Yes \\
\hline Manitoba & $\begin{array}{l}\text { Hospital location categories are identified in one field. } \\
\text { Services to other locations, including personal care } \\
\text { homes and patient home are identified from fee codes. } \\
\text { Clinic locations are identified from the billing location. }\end{array}$ & $\begin{array}{l}\text { Collected in a } \\
\text { separate database. } \\
\text { Available since } \\
1993 / 1994\end{array}$ & $\begin{array}{l}\text { Yes, but completeness } \\
\text { is unknown }\end{array}$ & $\begin{array}{l}\text { No. Shadow-billed claims } \\
\text { can be identified using } \\
\text { information contained in } \\
\text { the provider registry. }\end{array}$ \\
\hline Ontario & $\begin{array}{l}\text { In the current data, there is no field for location of service. } \\
\text { Locations are identified from fee codes and/or institution } \\
\text { numbers. A hospital master number is recorded for services } \\
\text { provided in hospital. }\end{array}$ & $\begin{array}{l}\text { Identified by a } \\
\text { numeric code in } \\
\text { the database or } \\
\text { by the fee code or } \\
\text { physician number }\end{array}$ & $\begin{array}{l}\text { Yes, but completeness } \\
\text { is unknown }\end{array}$ & Yes \\
\hline Quebec & $\begin{array}{l}\text { Two primary locations: private cabinet (e.g. office/clinic) } \\
\text { and establishment (e.g. hospital). For establishments, } \\
\text { there are } 40+\text { location categories including private firms, } \\
\text { hospitals, laboratory diagnostic radiology, office of } \\
\text { physiotherapy, home centres for children and youth, } \\
\text { federal agencies, universities, private clinics, private } \\
\text { labs orthotics-prosthetics, detention centres. }\end{array}$ & $\begin{array}{l}\text { Identified by a } \\
\text { numeric code } \\
\text { in the database }\end{array}$ & No & No \\
\hline $\begin{array}{l}\text { Prince Edward } \\
\text { Island }\end{array}$ & $\begin{array}{l}25 \text { codes are currently used: office, home visit, inpatient, } \\
\text { outpatient, other office, day surgery, specialty clinic, } \\
\text { community care facility, other site, UPEI clinic, detox } \\
\text { centres, First Patient, inpatient radiology, night clinic, } \\
\text { outpatient radiology, visiting specialist in Prince County } \\
\text { Hospital, visiting specialist in Queen Elizabeth hospital, } \\
\text { Saturday/Sunday office, radiology, provider in any facility } \\
\text { type, radiology emergency, walk-in clinic, public dental } \\
\text { facility, private dental facility, public health hygienist. }\end{array}$ & $\begin{array}{l}\text { Identified by a } \\
\text { numeric code } \\
\text { in the database }\end{array}$ & $\begin{array}{l}\text { Yes, but completeness is } \\
\text { unknown. Effective July } 1 \text {, } \\
\text { 2008, the Clinical Work } \\
\text { Incentive (an incentive to } \\
\text { shadow bill) was introduced, } \\
\text { at which time shadow-billing } \\
\text { has become more complete }\end{array}$ & $\begin{array}{l}\text { No. Shadow-billed claims } \\
\text { can be identified from } \\
\text { the physician billing or } \\
\text { specialty number. }\end{array}$ \\
\hline Nova Scotia & $\begin{array}{l}\text { Office, correctional centre, home hospital care, patient's } \\
\text { home, hospital, nursing home. Hospital locations include } \\
\text { detox, emergency, intensive care, inpatient, neonatal unit, } \\
\text { outpatient. }\end{array}$ & $\begin{array}{l}\text { Collected in a } \\
\text { separate database }\end{array}$ & $\begin{array}{l}\text { Yes, but completeness } \\
\text { is unknown }\end{array}$ & Yes, from 1997 onward. \\
\hline $\begin{array}{l}\text { Newfoundland } \\
\text { and Labrador }\end{array}$ & Home, office, inpatient, outpatient, emergency department. & $\begin{array}{l}\text { Collected in a } \\
\text { separate database }\end{array}$ & No & No \\
\hline Yukon & $\begin{array}{l}\text { Office/practitioner office, patient's home, hospital inpatient, } \\
\text { hospital outpatient, lab, surgery specialty clinic, community } \\
\text { care facility, other, out of town clinic, nursing home, injection, } \\
\text { anesthesia, assist surgery, admit, maternity, jail. }\end{array}$ & $\begin{array}{l}\text { Identified in one } \\
\text { field in the database }\end{array}$ & $\begin{array}{l}\text { Yes, but completeness } \\
\text { is unknown }\end{array}$ & Yes \\
\hline Nunavut & No field for location of service. & $\begin{array}{l}\text { Identified by a } \\
\text { numeric code } \\
\text { in the database }\end{array}$ & No & No \\
\hline
\end{tabular}

Abbreviation: UPEI, University of Prince Edward Island.

Note: Incomplete or no survey data was available for New Brunswick and Northwest Territories. As a result, these were excluded from the analysis.

the Saskatchewan database. ${ }^{16}$ However, previous research that compared prescription drug administrative databases in several Canadian provinces found differences in patient, provider and drug features. ${ }^{10}$ These findings are consistent with the findings of the current study, which revealed heterogeneity in many features of PSDs in Canada, including the years of available data, classification of provider specialty, database inclusions and exclusions, and coding of diagnoses, procedures and service locations.

PSDs have a tremendous potential to benefit population health and health services research and surveillance initiatives in Canada. The Canadian Chronic Disease Surveillance System uses administrative health databases to provide comparable, longitudinal data on chronic disease prevalence and incidence. This is used to support provincial and territorial surveillance efforts. Statistic Canada's Longitudinal Health and Administrative Data Initiative links administrative health databases with population health survey data, including data from the National Population Health Survey and Canadian Community Health Survey, to facilitate 
FIGURE 1

Full-time equivalent physicians receiving non-fee-for-service (alternate clinical) payments, by province, 1999/2000 and 2005/2006

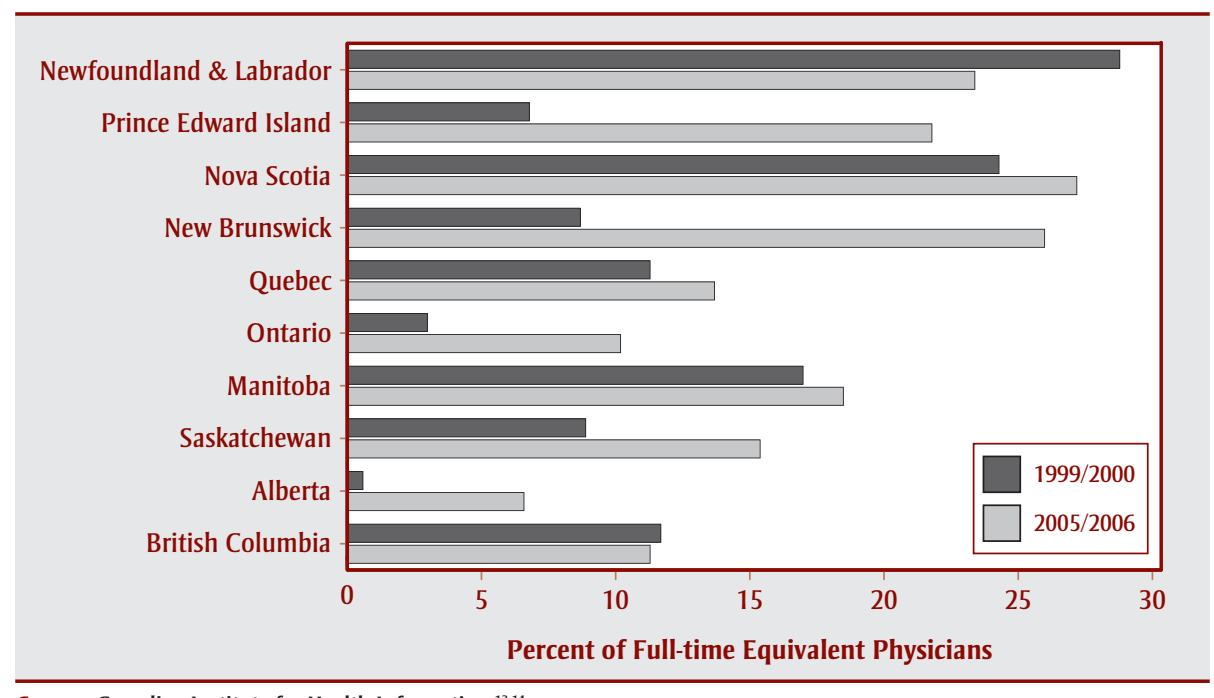

Source: Canadian Institute for Health Information. ${ }^{13,14}$

pan-Canadian research about determinants of health, health outcomes and their relationships. ${ }^{17}$

However, differences in PSDs across Canada are an important consideration for comparability of the findings from research and surveillance studies. Changes in disease prevalence estimates over time may be due, in part, to measurement artifact arising from changes in ICD coding systems rather than true change in the population distribution of disease. ${ }^{18}$ The incomplete capture of services by non-fee-for-service physicians may result in biased estimates of trends over time and differences across health regions. ${ }^{19}$ The number of years of available data might influence the results of studies about duration of disease exposure and time to disease onset. ${ }^{20}$ Text diagnosis fields, such as those found in the Yukon PSD, may require the use of data mining techniques to assign diagnosis codes, ${ }^{21}$ a different methodology than would be used in other jurisdictions to ascertain disease cases.

Some studies may not be feasible for all Canadian provinces and territories because of the differences in data coding systems. For example, some forms of arthritis cannot be identified using the first three digits of ICD-9. ${ }^{22}$ Ontario and Saskatchewan PSDs do not contain all codes from either the ICD-8 or ICD-9 systems; incomplete codes may result some limitations. The study relied on a purposive sample; the key informants may not have had complete information about features of PSDs over time or across the geographic regions of a province or territory. A second limitation is that the quality of the data associated with different features was not investigated. ${ }^{25}$ For example, this study did not examine accuracy or completeness of fields containing location of service codes.

Our study suggests a rich set of opportunities to examine further the use and comparability of PSDs in pan-Canadian research and surveillance initiatives. Previous research about the potential bias caused by the length of the observation period and incompleteness of data on prevalence and incidence estimation has often focused on cancer registries and on data from a single jurisdiction. ${ }^{26,27}$ Computer simulation and statistical modeling techniques that have been proposed to estimate or adjust for these effects ${ }^{28,29}$ could be extended to multiple jurisdictions. Methodological investigations about the utility of other administrative databases, such as prescription drug databases, to estimate the completeness of PSDs for chronic disease surveillance $^{8}$ could also be used for comparisons across many jurisdictions. A recent study about methods to ascertain chronic disease cases in administrative health databases emphasized the need to assess the validity of diagnosis codes

FIGURE 2

Non-fee-for-service (alternate clinical) payments to physicians, by province, $1999 / 2000$ and $2008 / 2009$

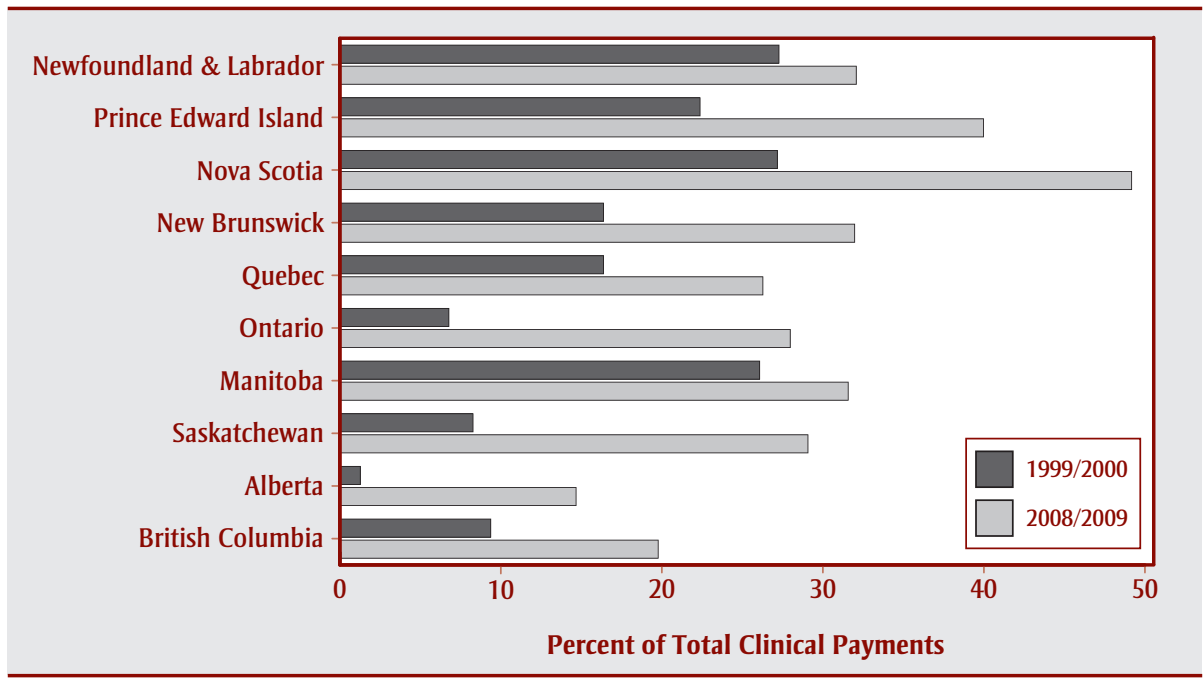

Source: Canadian Institute for Health Information. ${ }^{12}$ 
across populations and over time to ensure the generalizability of case-detection algorithms. ${ }^{30}$ There are other features of PSDs that require investigation, including data access procedures, service fee codes, and processes for data linkage. For example, substantial differences have been observed in service fees for colonoscopy and endoscopy using provincial and territorial fee schedules. ${ }^{11}$ There may also be differences in the types of procedures and services for which fee codes have been developed. While there are an increasing number of studies that link PSDs to other administrative, clinical and population-based survey data sources, ${ }^{31-33}$ we did not consider how the capability to conduct these linkages might vary across provinces and territories.

In summary, this study has demonstrated differences across provinces and territories in a number of PSDs features. This may affect the comparability of pan-Canadian research and surveillance. Studies that investigate the potential impact of these differences will benefit Canadian researchers, epidemiologists and health care decision makers.

\section{Acknowledgements}

This study was supported by funding from the Canadian Institutes of Health Research to LML and HQ and the University of Saskatchewan Centennial Research Chair Program to LML. The authors are indebted to the many individuals who participated in this study, including Michael A. Ruta (Government of Nunavut); Dr. Gillian Bartlett (McGill University); Deanna Rothwell (The Ottawa Hospital, The Ottawa Hospital Research Institute, and the Institute of Clinical Evaluative Sciences); Nedeene R. L. Hudema (Saskatchewan Health Quality Council), Nadine MacLean (Health PEI); Dr. Carol McClure (PEI Department of Health and Wellness); Dr. Khokan C. Sikdar (Newfoundland and Labrador Centre for Health Information); Robert Fisk, Kim Reimer and Jenny Sutherland (Population Health Surveillance and Epidemiology Population and Public Health, BC Ministry of Health); Mike Tribes (consultant, Yukon) and Charles Burchill (Manitoba Centre for Health Policy, University of Manitoba).
The authors also acknowledge the investigators of the Hypertension Outcomes and Surveillance Team, including Dr. Karen Tu, Dr. Brenda Hemmelgarn, Dr. Norman Campbell, Dr. Finlay McAlister, Dr. Michael Hill, Dr. Nadia Khan, Dr. Andreas Wielgosz, Dr. Gary Teare, Mark Smith, Larry Svenson, Dr. Oliver Baclic, Dr. Gillian Bartlett, Dr. Sulan Dai, Jay Onysko, and Dr. Helen Johansen.

This study is based, in part, on information provided by the Saskatchewan Ministry of Health. The interpretation and conclusions contained herein do not necessarily represent those of the Government of Saskatchewan or the Saskatchewan Ministry of Health.

\section{References}

1. Clottey C, Mo F, LeBrun B, Mickelson P, Niles J, Robbins G. The development of the National Diabetes Surveillance System (NDSS) in Canada. Chronic Dis Can. 2001;22:67-9.

2. Khan L, Mincemoyer S, Gabbay RA. Diabetes registries: where we are and where are we headed? Diabetes Technol Ther. 2009;11:255-62.

3. Dai S, Robitaille C, Bancej C, Loukine L, Waters C, Baclic O. Executive summaryreport from the Canadian Chronic Disease Surveillance System: hypertension in Canada, 2010. Chronic Dis Can. 2010;31:46-7.

4. Bernatsky S, Joseph L, Pineau CA, Bélisle P, Boivin JF, Banerjee D, et al. Estimating the prevalence of polymyositis and dermatomyositis from administrative data: age, sex, and regional differences. Ann Rheum Dis. 2009;68:1192-6.

5. Bernstein $\mathrm{CN}$, Wajda A, Svenson LW et al. The epidemiology of inflammatory bowel disease in Canada: a population-based study. Am J Gastroenterol. 2006;101:1559-68.

6. Kisely $\mathrm{S}$, Lin E, Lesage A, MacKenzie A, Koehoorn M, Jackson $M$, et al. Use of administrative data for the surveillance of mental disorders in 5 provinces. Can J Psychiatry. 2009;54:571-5.
7. Campbell N, Onysko J; Canadian Hypertension Education Program; Outcomes Research Task Force. The Outcomes Research Task Force and the Canadian Hypertension Education Program. Can J Cardiol. 2006;22:556-8.

8. Alshammari AM, Hux JE. The impact of non-fee-for-service reimbursement on chronic disease surveillance using administrative data. Can J Public Health. 2009;100:472-4.

9. Campbell N, Chen G. Canadian efforts to prevent and control hypertension. Can J Cardiol. 2010;26(Suppl C):14C-17C.

10. Miller E, Blatman B, Einarson TR. A survey of population-based drug databases in Canada. CMAJ. 1996;154:1855-64.

11. Roth LS, Adams PC. Variation in physician reimbursement for endoscopy across Canada. Can J Gastroenterol. 2009;23:503-5.

12. Canadian Institute for Health Information. National physician database, 2008-2009. Ottawa (ON): Canadian Institute for Health Information; 2010.

13. Canadian Institute for Health Information. Physicians in Canada: the status of alternate payment programs, 1999-2000. Ottawa (ON): Canadian Institute for Health Information; 2001.

14. Canadian Institute for Health Information. Physicians in Canada: the status of alternative payment programs, 2005-2006. Ottawa (ON): Canadian Institute for Health Information; 2008.

15. Canadian Institute for Health Information. Profiling physicians by payment program: a closer look at three provinces. Ottawa (ON): Canadian Institute for Health Information; 2010.

16. Downey W, Beck C, McNutt M, Stang M, Osei W, Nichol J. Health databases in Saskatchewan. In: Strom BL, ed. Pharmacoepidemiology, 3rd ed. New York: Wiley; 2000;325-45.

17. Statistics Canada. About the longitudinal health and administrative data initiative. Health Research Working Paper Series [Internet]. Ottawa (ON): Statistics Canada; 2011 [accessed 2011 Nov 28]. Available from: http://www.statcan.gc.ca/pub/82-622-x /2011008/intro-eng.htm 
18. Statistics Canada. Comparability of ICD-10 and ICD-9 for mortality statistics in Canada. 84-548-XIE [Internet]. Ottawa (ON): Statistics Canada; 2005 [accessed 2011 Nov 28]. Available from: http://www.statcan.gc.ca /pub/84-548-x/84-548-x2005001-eng.htm

19. Parkin DM, Bray F. Evaluation of data quality in the cancer registry: principles and methods Part II. Completeness. Eur J Cancer. 2009;45:756-64.

20. Cox E, Martin BC, Van Staa T, Garbe E, Siebert U, Johnson ML. Good research practices for comparative effectiveness research: approaches to mitigate bias and confounding in the design of nonrandomized studies of treatment effects using secondary data sources: The International Society for Pharmacoeconomics and Outcomes Research Good Research Practices for Retrospective Database Analysis Task Force Report-Part II. Value in Health. 2009;12:1053-61.

21. Mullins IM, Siadaty MS, Lyman J, Scully K, Garrett CT, Miller WG, et al. Data mining and clinical data repositories: insights from a 667,000 patient data set. Comput Biol Med. 2006;36:1351-77.

22. Katz JN, Barrett J, Liang MH, Bacon AM, Kaplan H, Kieval RI, et al. Sensitivity and positive predictive value of Medicare Part B physician claims for rheumatologic diagnoses and procedures. Arthritis Rheum. 1997;40:1594-1600.

23. Leslie WD, Tsang JF, Lix LM. Validation of ten-year fracture risk prediction: a clinical cohort study from the Manitoba Bone Density Program. Bone 2008;43:667-71.

24. Jean S, Candas B, Belzile E, Morin S, Bessette L, Dodin S, et al. Algorithms can be used to identify fragility fracture cases in physician-claims databases. Osteoporos Int. 2012;23:483-501.

25. Karr AF, Sanil AP, Banks DL. Data quality: a statistical perspective. Stat Methodol. 2006;3:137-73.

26. McClish D, Penberthy L. Using multivariate capture-recapture techniques and statewide hospital discharge data to assess the validity of a cancer registry for epidemiologic use. Health Serv Outcomes Res Methodol. 2004;5:141-52.
27. Capocaccia R, de Angelis R. Estimating the completeness of prevalence based on cancer registry data. Stat Med. 1997;16:425-40.

28. Silcocks PB, Robinson D. Simulation modelling to validate the flow method for estimating completeness of case ascertainment by cancer registries. J Public Health. 2007;29:455-62.

29. Bernatsky S, Joseph L, Belisle P, Boivin JF, Rajan R, Moore A, et al. Bayesian modelling of imperfect ascertainment methods in cancer studies. Stat Med. 2005;24:2365-79.

30. Manuel DG, Rosella LC, Stukel TA. Importance of accurately identifying disease in studies using electronic health records. BMJ. 2010;341:c4226.

31. Lix LM, Yogendran MS, Shaw SY, Burchill C, Metge C, Bond R. Population-based data sources for chronic disease surveillance. Chron Dis Can. 2008;29:31-8.

32. Muhajarine N, Mustard C, Roos LL, Young TK, Gelskey DE. Comparison of survey and physician claims data for detecting hypertension. J Clin Epidemiol. 1997;50:711-8.

33. Roos LL, Brownell M, Lix L, Roos NP, Walld R, MacWilliam L. From health research to social research: privacy, methods, approaches. Soc Sci Med. 2008;66:117-29. 